\title{
Evidence from genetic and Lagrangian drifter data for transatlantic transport of small juvenile green turtles
}

\author{
C. Monzón-Argüello ${ }^{1,2,3}$, L. F. López-Jurado² ${ }^{2}$ C. Rico ${ }^{3}$, A. Marco ${ }^{3}$, P. López ${ }^{4}$, \\ G. C. Hays ${ }^{5}$ and P. L. M. Lee $e^{5 *}$
}

${ }^{1}$ Instituto Canario de Ciencias Marinas, Carretera de Taliarte s/n, 35200 Telde, Gran Canaria, Spain, ²Departamento de Biología, Universidad de Las Palmas de G.C. Campus de Tafira, 35017 Las Palmas de Gran Canaria, Gran Canaria, Spain, ${ }^{3}$ Estación Biológica de Doñana (CSIC), Américo Vespucio, s/n, 41092 Sevilla, Spain, ${ }^{4}$ Naturalia, Cape Verde Ltd., Sal-Rei, Boa Vista, Republic of Cape Verde, ${ }^{5}$ Department of Pure and Applied Ecology, Institute of Environmental Sustainability, Swansea University, Swansea SA2 8PP, UK

*Correspondence: Patricia L. M. Lee, Department of Pure and Applied Ecology, Institute of Environmental Sustainability, Swansea University, Swansea SA2 8PP, UK. E-mail: p.l.m.lee@swansea.ac.uk

\section{ABSTRACT}

Aim A key life-history component for many animals is the need for movement between different geographical locations at particular times. Green turtle (Chelonia mydas) hatchlings disperse from their natal location to spend an early pelagic stage in the ocean, followed by a neritic stage where small juveniles settle in coastal areas. In this study, we combined genetic and Lagrangian drifter data to investigate the connectivity between natal and foraging locations. In particular we focus on the evidence for transatlantic transport.

Location Atlantic Ocean.

Methods We used mitochondrial DNA (mtDNA) sequences $(n=1567)$ from foraging groups $(n=8)$ and nesting populations $(n=12)$ on both sides of the Atlantic. Genetic data were obtained for Cape Verde juvenile turtles, a foraging group not previously sampled for genetic study. Various statistical methods were used to explore spatial genetics and population genetic structure (e.g. exact tests of differentiation, Geneland and analysis of molecular variance). Many-to-many mixed stock analysis estimated the connectivity between nesting and foraging groups.

Results Our key new finding is robust evidence for connectivity between a nesting population on the South American coast (25\% of the Surinam nesting population are estimated to go to Cape Verde) and a foraging group off the coast of West Africa (38\% of Cape Verde juveniles are estimated to originate from Surinam), thus extending the results of previous investigations by confirming that there is substantial transatlantic dispersal in both directions. Lagrangian drifter data demonstrated that transport by drift across the Atlantic within a few years is possible.

Main conclusions Small juvenile green turtles seem capable of dispersing extensively, and can drop out of the pelagic phase on a transatlantic scale (the average distance between natal and foraging locations was $3048 \mathrm{~km}$ ). Nevertheless, we also find support for the 'closest-to-home' hypothesis in that the degree of contribution from a nesting population to a foraging group is correlated with proximity. Larger-sized turtles appear to feed closer to their natal breeding grounds (the average distance was $1133 \mathrm{~km}$ ), indicating that those that have been initially transported to far-flung foraging grounds may still be able to move nearer to home as they grow larger.

Keywords

Atlantic Ocean, buoy trajectory data, Chelonia mydas, foraging grounds, geographical connectivity, landscape genetics, mitochondrial DNA, mixed stock analysis. 


\section{INTRODUCTION}

Understanding how organisms are distributed and dispersed in space and time, and how they achieve this, are key objectives in biogeography. Evolutionary models and empirical studies show that multiple factors influence the costs and benefits of dispersal (Bowler \& Benton, 2005; Dawson \& Hamner, 2008). In the sea, the pelagic juvenile stage represents an important dispersal mechanism, but dispersal could be affected by oceanographic factors or life-history traits (Palumbi, 2004). Some of the most remarkable movements are by marine animals, with some species migrating thousands of kilometres while returning to their natal areas to reproduce (Bowen et al., 1992; Lohmann et al., 1999; Putman \& Lohmann, 2008). Green turtles, Chelonia mydas (Linnaeus, 1758), constitute such an example, exhibiting a complex life-history pattern with weak migratory connectivity (Bolten, 2003; Bolker et al., 2007; Bjorndal \& Bolten, 2008). Their life begins in specific geographical areas, followed by dispersal across vast expanses of sea (Lohmann et al., 1999, 2008a,b). This first stage is spent in the open ocean for 3 to 5 years (Carr \& Meylan, 1980; Reich et al., 2007), although this period could be longer (Zug et al., 2002; McClellan \& Read, 2007). After that, juveniles of approximately $20-40 \mathrm{~cm}$ in curve carapace length (CCL) (or $18-37 \mathrm{~cm}$ in straight carapace length, SCL) settle into neritic benthic habitats as herbivores (Bjorndal, 1980; Balazs, 1982; Musick \& Limpus, 1997). This habitat shift is relatively rapid and direct, although variation in temperature, diet quality and/ or food availability could affect recruitment size (Reich et al., 2007). Following settlement, green sea turtles may undertake further developmental migrations among neritic foraging grounds, but after several decades sexual maturity is attained and adults migrate back to their natal areas to reproduce (Lohmann et al., 1999, 2008a,b; Bjorndal \& Bolten, 2008).

Previous studies indicate that a variety of factors may influence the composition of a neritic foraging group (FG), including: nesting population (NP) size (Bass et al., 1998; Lahanas et al., 1998), geographical distance (Bass \& Witzell, 2000), oceanic currents (Luke et al., 2004; Bass et al., 2006; Naro-Maciel et al., 2007) and homing behaviour (Bowen et al., 2004; Bass et al., 2006; Bolker et al., 2007). Of these, currents and homing behaviour have been the key focus for formulating hypotheses.

Recently, genetic studies have looked at sampling gaps in the western coast of Africa (Formia et al., 2006), and these have enabled larger-scaled mixed stock analyses (MSAs) to better resolve the movements of green turtles in the Atlantic Ocean (Bolker et al., 2007; Naro-Maciel et al., 2007). In an important advance, Bolker et al. (2007) developed a Bayesian hierarchical model ('many-to-many' MSA) that simultaneously estimates the origins ('foraging group-centric' perspective) and destinations ('nesting population-centric' perspective) of individuals in a metapopulation with several source populations ('rookeries' or NPs) and many mixed stocks, with rookery size as a constraint in the analysis. This resulted in novel insights, for example that there were greater contributions than previously thought to distant FGs, with extensive connectivity among NPs and FGs within three broad regions. The authors suggested that the latter pattern could be caused by the tendency of immature turtles to settle in FGs closest to their natal beach, but noted that within regions the 'closest-to-home' hypothesis did not always hold. One of the most important outcomes was the observation that transatlantic dispersal was possible. They showed that the Guinea Bissau (West Africa) NP was an important contributor to foraging assemblages on the north-east Brazilian coast. There was also an indication of connectivity in the other direction, between a north-east Brazilian NP and a West African FG, but this was not supported by the 'many-to-many' analysis.

Here, we extend the study of Bolker et al. (2007) by adding new data for a West African FG not previously studied, with the aim of establishing further evidence for transatlantic dispersal of early juvenile green turtles. Additionally, we mined Lagrangian drifter data to find out whether ocean currents would allow for such transport. Finally, we attempt to compare the average distances between natal and foraging locations for small-sized juveniles versus larger-sized turtles.

\section{MATERIALS AND METHODS}

\section{Sampling, data collection and DNA sequencing}

We focus on the shift from pelagic to benthic habitats by examining coastal areas where juveniles of approximately 2040 cm CCL (18-37 cm SCL; hereafter called small juveniles) can be found. As size data for each individual sampled for genetic study were not available, we used size range information and found eight FGs that include these body sizes (SCL size range $24.0-78.7 \mathrm{~cm}$; Table 1 ). These are considered to be FGs where small juveniles are likely to first drop out of the pelagic phase (hereafter called small-sized foraging groups, ssFGs) because they include individuals of the sizes that are expected of such turtles (i.e. below $40 \mathrm{~cm}$ CCL, or $37 \mathrm{~cm} \mathrm{SCL).}$ We also employed one FG with turtles of larger body sizes (hereafter called the large-sized foraging group, lsFG) that did not overlap with the sizes of those in ssFGs (Nicaragua; Table 1), and must therefore represent later life stages. We used 1567 mitochondrial DNA (mtDNA) control region sequences of green turtles in the Atlantic, incorporating data published up to 2008 for NPs and FGs (Fig. 1, Tables 1 \& 2). Most of the locations (Fig. 1, Table 1) are as named by Bolker et al. (2007), with the exception of: (1) Rocas Atoll, previously called north-east Brazil; (2) Bioko and São Tomé and Príncipe, formerly grouped as the Gulf of Guinea; and (3) the Rocas Atoll foraging group, previously called north-east Brazil. We added data for Ubatuba and Almofala (Brazil; Fig. 1) that had been subsequently published (Naro-Maciel et al., 2007). Although the genetic data for the Corisco Bay FG were reported in a thesis (Formia, 2002), they were not included here since they were not formally published by the author at the time of our analysis. We added new genetic data for the FG of the Cape Verde Islands, a location off the West African coast not previously studied. 
Table 1 References for the dataset used in this study. Size information for the analysed green turtles (Chelonia mydas) is given by the straight carapace length (SCL) in centimetres.

\begin{tabular}{|c|c|c|c|c|c|c|c|}
\hline Location & Area & SCL & Type of FG & Pop. size & $\mathrm{h}$ & $\mathrm{p}$ & References \\
\hline Nicaragua & Foraging & 88.3-105.7 & lsFG & - & $0.183 \pm 0.062$ & $0.0038 \pm 0.0025$ & Bass et al. (1998) \\
\hline Florida & Foraging & $25.0-70.0$ & ssFG & - & $0.485 \pm 0.067$ & $0.0031 \pm 0.0021$ & Bass \& Witzell (2000) \\
\hline N. Carolina & Foraging & $24.0-74.0$ & ssFG & - & $0.678 \pm 0.031$ & $0.0051 \pm 0.0031$ & Bass et al. (2006) \\
\hline Bahamas & Foraging & $31.0-67.0$ & ssFG & - & $0.370 \pm 0.065$ & $0.0064 \pm 0.0037$ & Lahanas et al. (1998) \\
\hline Barbados & Foraging & $31.0-70.0$ & ssFG & - & $0.773 \pm 0.028$ & $0.0103 \pm 0.0056$ & Luke et al. (2004) \\
\hline Ubatuba & Foraging & *30.7-73.7 & ssFG & - & $0.446 \pm 0.056$ & $0.0020 \pm 0.0015$ & Naro-Maciel et al. (2007) \\
\hline Almofala & Foraging & $* 27.7-78.7$ & ssFG & - & $0.717 \pm 0.031$ & $0.0068 \pm 0.0039$ & Naro-Maciel et al. (2007) \\
\hline Rocas Atoll & Foraging & No data & ssFG & - & $0.644 \pm 0.092$ & $0.0022 \pm 0.0017$ & Bjorndal et al. (2006) \\
\hline Cape Verde & Foraging & $25.5-58.3$ & ssFG & - & $0.587 \pm 0.045$ & $0.0042 \pm 0.0027$ & Present study \\
\hline Mexico & Nesting & - & - & 1587 & $0.816 \pm 0.057$ & $0.0051 \pm 0.0032$ & Encalada et al. (1996) \\
\hline Florida & Nesting & - & - & 779 & $0.562 \pm 0.047$ & $0.0012 \pm 0.0011$ & Encalada et al. (1996) \\
\hline Costa Rica & Nesting & - & - & 26535 & $0.163 \pm 0.023$ & $0.0033 \pm 0.0021$ & Bjorndal et al. (2005) \\
\hline Aves & Nesting & - & - & 267 & $0.186 \pm 0.088$ & $0.0039 \pm 0.0025$ & Lahanas et al. (1998) \\
\hline Surinam & Nesting & - & - & 1814 & $0.257 \pm 0.142$ & $0.0030 \pm 0.0021$ & Encalada et al. (1996) \\
\hline Rocas Atoll & Nesting & - & - & 115 & $0.537 \pm 0.075$ & $0.0026 \pm 0.0018$ & $\begin{array}{l}\text { Encalada et al. (1996), } \\
\text { Bjorndal et al. (2006) }\end{array}$ \\
\hline Trindade Is. & Nesting & - & - & 3000 & $0.505 \pm 0.052$ & $0.0012 \pm 0.0011$ & Bjorndal et al. (2006) \\
\hline Guinea Bissau & Nesting & - & - & 2523 & $0.000 \pm 0.000$ & $0.0000 \pm 0.0000$ & $\begin{array}{l}\text { Encalada et al. (1996), } \\
\text { Formia et al. (2006) }\end{array}$ \\
\hline Ascension Is. & Nesting & - & - & 3709 & $0.289 \pm 0.071$ & $0.0007 \pm 0.0008$ & $\begin{array}{l}\text { Encalada et al. (1996), } \\
\text { Formia et al. (2006) }\end{array}$ \\
\hline $\begin{array}{l}\text { Sâo Tomé and } \\
\text { Príncipe }\end{array}$ & Nesting & - & - & 90 & $0.569 \pm 0.110$ & $0.0026 \pm 0.0019$ & Formia et al. (2006) \\
\hline Bioko & Nesting & - & - & 407 & $0.184 \pm 0.068$ & $0.0004 \pm 0.0005$ & Formia et al. (2006) \\
\hline Cyprus & Nesting & - & - & 100 & $0.077 \pm 0.070$ & $0.0002 \pm 0.0003$ & $\begin{array}{l}\text { Encalada et al. (1996), } \\
\text { Kaska (2000) }\end{array}$ \\
\hline
\end{tabular}

*Data originally collected as curved carapace length (CCL) (McClellan \& Read, 2007) were transformed to SCL using the equation CCL $=1.388+$ (1.053) SCL (Bjorndal et al., 2000).

Population size data were obtained from Bellini et al. (1995), Seminoff (2002, 2004) and Formia et al. (2006). Haplotype (h) and nucleotide (p) diversities detected at each location are shown. Type of foraging group (FG) is shown: small-sized foraging group (ssFG) and large-sized foraging group (lsFG).

Forty-four tissue samples from Boavista Island (Cape Verde) were collected in a $20 \%$ DMSO (dimethyl sulfoxide) solution or 96\% ethanol during 2001, 2007 and 2008. Genomic DNA was isolated using the DNeasy Tissue Kit (Qiagen, Hamburg, Germany). A 760-base pair (bp) fragment of the mtDNA control region was amplified by polymerase chain reaction (PCR) (Abreu-Grobois et al., 2006). Up to $2 \mathbf{1 L}$ of extracted DNA (60 ng) was used in 20 lL PCR mixes containing 0.5 lm of each primer, $0.25 \mathrm{~mm}$ dNTPs (deoxyribonucleoside triphosphates), $0.6 \mathrm{U}$ of Taq DNA polymerase (Bioline, London, UK), 1 - PCR buffer (Bioline), $0.21 \mathrm{lg} 1 \mathrm{~L}^{1}$ bovine serum albumin (BSA) and $2 \mathrm{~mm} \mathrm{MgCl}_{2}$ (Bioline). The thermal conditions were an initial denaturation step at $94{ }^{\circ} \mathrm{C}$ for $2 \mathrm{~min}$, followed by 40 cycles of $94^{\circ} \mathrm{C}$ for $1 \mathrm{~min}, 55^{\circ} \mathrm{C}$ for $1 \mathrm{~min}$ and $72{ }^{\circ} \mathrm{C}$ for $1 \mathrm{~min}$, with a final extension at $72{ }^{\circ} \mathrm{C}$ for $5 \mathrm{~min}$. Cycle sequencing was with the Big Dye fluorescent dye-terminator and the fragments analysed on model 3100 or 3730 automated sequencers (Applied Biosystems Inc., Foster City, CA, USA). Chromatograms were aligned using Bioedit Sequence Alignment Editor v.7.0.9 (http://www.mbio. ncsu.edu/BioEdit/bioedit.html) or Sequencher v.3.1.2 (Gene Codes Corporation, Ann Arbor, MI, USA).

\section{Sequence data analyses}

Our control region sequence alignment was trimmed to 486 bp and classified according to standardized nomenclature (Archie Carr Center for Sea Turtle Research, ACCSTR; http:// accstr.ufl.edu/ccmtdna.html). Haplotype frequencies, Nei's (1987) haplotype diversity (h) and nucleotide diversity (p) of mtDNA sequences were measured using Arlequin v.3.11 (Excoffier et al., 2005). FindModel (http://www.hiv.lanl.gov/ content/sequence/findmodel/findmodel.html) determined the best model of nucleotide substitution that fits the data. Exact tests of population differentiation (Raymond \& Rousset, 1995) used a Markov chain length of 10,000 steps with 1000 dememorization steps.

Bayesian clustering algorithms (http://www2.imm.dtu.dk/ gigu/Geneland/) were applied to infer population structure (number of clusters, K) and assign individuals to clusters (Guillot et al., 2005). Sequences were recoded as instructed in the Geneland v. 3.1.4 program documentation and a model with multinomial distribution of genotypes conditional on uncorrelated allele frequencies and population memberships together with linkage equilibrium was assumed. Spatial 


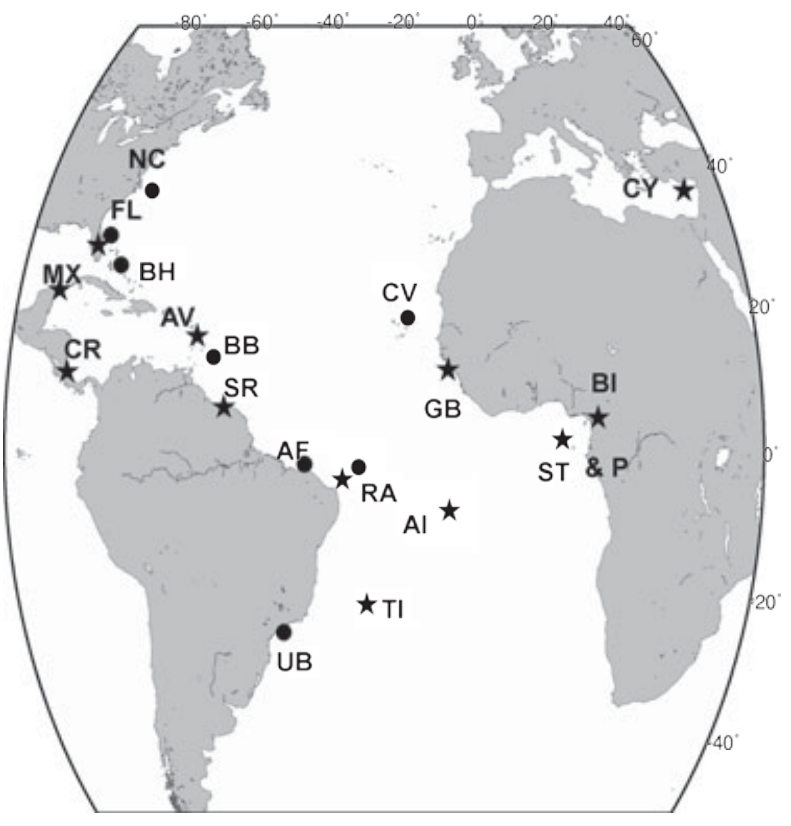

Figure 1 Map of the Atlantic Ocean and Mediterranean Sea showing locations for green turtle (Chelonia mydas) nesting populations (stars) and small-sized foraging groups (circles) with abbreviated names using a Mollweide projection: NC, North Carolina; FL, Florida; MX, Mexico; BH, Bahamas; CR, Costa Rica; AV, Aves Island; BB, Barbados; SR, Surinam; AF, Almofala; RA, Rocas Atoll; UB, Ubatuba; TI, Trindade Island; AI, Ascension Island; CV, Cape Verde; GB, Guinea Bissau; BI, Bioko; ST \& P, Sâo Tomé and Príncipe; CY, Cyprus.

coordinates for NP and FG locations were entered into Geneland, which uses models based on free Voronoi tessellation where spatial domains of inferred clusters are approximated by polygons constructed independently of sampling locations. Spatial clustering models potentially achieve more accurate results than non-spatial models for datasets characterized by low levels of genetic differentiation and/or a small number of loci (Guillot et al., 2009). Individual-based Bayesian clustering used by Geneland means that the georeferenced haplotypes are assigned to the inferred clusters without any prior knowledge of the population units and limits (Guillot et al., 2005), which is different from the more traditional method of using predefined populations (Waples \& Gaggiotti, 2006). NPs and ssFGs were analysed separately. The first run inferred $\mathrm{K}$, and the second run, with $\mathrm{K}$ fixed at the modal value, assigned individuals to inferred populations. The first step was replicated 10 times to check for convergence, allowing $\mathrm{K}$ to vary from 1 to 10 clusters and using 200,000 Markov chain Monte Carlo (MCMC) iterations, a burn-in of 200 and an uncertainty associated with the spatial coordinates of 0.1 . The number of clusters $(\mathrm{K})$ was inferred from the modal value of $\mathrm{K}$ for these runs. Runs were then sorted according to mean posterior density and only the best run was post-processed to obtain posterior probabilities of population membership for each individual and each pixel of the spatial domain. With the NPs, Geneland estimated a clear mode at $\mathrm{K}=5$ across 10 replicates. To further support these results, analysis of molecular variance (AMOVA; Arlequin v.3.11) employing $\mathrm{U}_{\mathrm{ST}}$ distances and 10,000 permutations (Excoffier et al., 2005) was performed. This examined how the differentiation was partitioned among the groups; the first using the clusters identified for NPs by Bayesian clustering analysis, and the other with individual ssFGs.

When Bolker et al. (2007) compared their new 'many-tomany' MSA method with the classic 'many-to-one' MSA (Pella \& Masuda, 2001), they obtained qualitatively similar results but with increased precision (lower coefficients of variation). We tested both methodologies with the new Cape Verde samples and obtained similar mean estimates but much lower standard deviation (SD) values with the new approach (the average SD decreases from 0.097 'many-to-one' to 0.048 'many-to-many'). Consequently, we proceeded with the 'many-to-many' MSA (Bolker et al., 2007) using the software winbugs (Spiegelhalter et al., 2004). This excludes 'orphan' haplotypes (haplotypes found in FGs but not in NPs), and all sets of haplotypes found only in a single NP are lumped together. Sources need to be reasonably well characterized, including their relative population sizes, while the mixed stocks allow for an 'unknown' category (Bolker et al., 2007). We used all published NP sizes (Table 1) (Bellini et al., 1995; Seminoff, 2002, 2004; Formia et al., 2006) as prior information and the analyses were performed until Gelman and Rubin diagnostics confirmed convergence of the chains to the posterior distribution, with values close to 1.0 and less than 1.2 (Pella \& Masuda, 2001). The results are presented in two ways: first a 'nesting population-centric' MSA that estimates the proportion of individuals from each NP that go to each FG; then a 'foraging group-centric' MSA that gives the proportion of individuals in each FG that originates from each NP.

\section{Estimating average distances travelled between nesting and foraging locations}

As it is not possible to tag or track small hatchlings, the MSA results were used to estimate the average distances of FGs from NPs. However, genetic data for the larger size class of green turtles (lsFG) were only available from one location, Nicaragua. Therefore, we used information from tagging and satellite-tracking studies of adult turtles to estimate distances for further lsFGs. Satellite tracking data came from females equipped on nesting beaches. Females remain in residence close to the nesting beaches during an extended breeding season that may last several months, during which time they lay several clutches of eggs. The movements made by females between clutches within the breeding season are generally small, both for green turtles (Hays et al., 1999) and several other species (e.g. Hays et al., 1991; Schofield et al., 2007, 2009). At the end of the nesting season female green turtles, along with other species, generally travel to specific foraging sites to which they generally maintain long-term fidelity (e.g. Godley et al., 2003a; Lohmann et al., 2008a). These foraging 
Table 2 Green turtle (Chelonia mydas) mitochondrial DNA (mtDNA) control region haplotypes detected at Cape Verde (CV) and other Atlantic groups from the published literature. Absolute frequencies are shown for foraging groups and nesting populations. Abbreviations for each site, except for NI (Nicaragua), are defined in Fig. 1.

\begin{tabular}{|c|c|c|c|c|c|c|c|c|c|c|c|c|c|c|c|c|c|c|c|c|c|}
\hline & \multicolumn{9}{|c|}{ Foraging groups } & \multicolumn{12}{|c|}{ Nesting populations } \\
\hline & $\mathrm{CV}$ & FL & $\mathrm{NC}$ & $\mathrm{NI}$ & $\mathrm{BB}$ & $\mathrm{BH}$ & RA & UB & $\mathrm{AF}$ & FL & MX & CR & $\mathrm{AV}$ & SR & RA & TI & $\mathrm{AI}$ & GB & $\mathrm{CY}$ & BI & ST\&P \\
\hline Total & 44 & 62 & 97 & 60 & 60 & 80 & 23 & 114 & 117 & 24 & 20 & 433 & 30 & 15 & 3 & 99 & 70 & 70 & 26 & 50 & 20 \\
\hline CM-A1 & 0.02 & 0.19 & 0.35 & & 0.12 & 0.03 & & & & 0.46 & 0.35 & & & & & & & & & & \\
\hline CM-A2 & & 0.02 & 0.02 & & & & & & & 0.04 & & & & & & & & & & & \\
\hline CM-A3 & 0.05 & 0.69 & 0.44 & 0.90 & 0.35 & 0.78 & & 0.02 & 0.15 & 0.50 & 0.25 & 0.91 & 0.10 & & & & & & & & \\
\hline CM-A4 & & & & & & & & & & & & 0.002 & & & & & & & & & \\
\hline CM-A5 & 0.52 & 0.05 & 0.05 & 0.10 & 0.22 & 0.13 & 0.22 & 0.12 & 0.24 & & 0.05 & 0.07 & 0.90 & 0.87 & & & & & & & 0.05 \\
\hline CM-A6 & 0.02 & & & & & & 0.09 & & 0.03 & & & & & 0.07 & & & 0.04 & & & 0.10 & 0.05 \\
\hline CM-A7 & & & & & & & & & & & & & & 0.07 & & & & & & & \\
\hline CM-A8 & 0.39 & & 0.07 & & 0.23 & 0.01 & 0.57 & 0.73 & 0.45 & & & & & & 0.68 & 0.68 & 0.84 & 1.00 & & 0.90 & 0.65 \\
\hline CM-A9 & & & & & 0.02 & & 0.09 & 0.04 & 0.03 & & & & & & 0.13 & 0.19 & 0.01 & & & & \\
\hline CM-A10 & & & & & 0.03 & & & 0.03 & 0.03 & & & & & & 0.04 & & 0.04 & & & & \\
\hline CM-A11 & & & & & & & & & & & & & & & 0.02 & 0.01 & & & & & \\
\hline CM-A12 & & & & & & & & & & & & & & & 0.09 & & & & & & \\
\hline CM-A13 & & & & & & & & & & & & & & & & & & & 0.96 & & \\
\hline CM-A14 & & & & & & & & & & & & & & & & & & & 0.04 & & \\
\hline CM-A15 & & & 0.01 & & & & & & & & 0.05 & & & & & & & & & & \\
\hline CM-A16 & & & 0.02 & & & & & & 0.01 & & 0.05 & & & & & & & & & & \\
\hline CM-A17 & & & & & 0.02 & & & & & & 0.10 & & & & & & & & & & \\
\hline CM-A18 & & 0.03 & 0.03 & & & & & & & & 0.15 & & & & & & & & & & \\
\hline CM-A20 & & & & & & 0.01 & & & & & & 0.005 & & & & & & & & & \\
\hline CM-A21 & & & & & & 0.04 & & & 0.01 & & & 0.01 & & & & & & & & & \\
\hline CM-A22 & & 0.02 & & & 0.02 & & & & & & & & & & & & & & & & \\
\hline CM-A23 & & & & & & & & & & & & & & & & 0.06 & & & & & \\
\hline CM-A24 & & & & & & & & 0.02 & 0.01 & & & & & & & 0.01 & 0.01 & & & & \\
\hline CM-A25 & & & & & & & & & & & & & & & 0.02 & & & & & & \\
\hline CM-A32 & & & & & & & & 0.02 & 0.01 & & & & & & 0.02 & 0.04 & & & & & \\
\hline CM-A33 & & & & & & & & & & & & & & & & 0.01 & & & & & \\
\hline CM-A35 & & & & & & & & & & & & & & & & & & & & & 0.05 \\
\hline CM-A36 & & & & & & & & & & & & & & & & & & & & & 0.05 \\
\hline CM-A37 & & & & & & & & & & & & & & & & & & & & & 0.05 \\
\hline CM-A38 & & & & & & & & & & & & & & & & & & & & & 0.10 \\
\hline CM-A39 & & & & & & & & & & & & & & & & & 0.01 & & & & \\
\hline CM-A42 & & & & & & & & & 0.02 & & & & & & & & & & & & \\
\hline CM-A44 & & & & & & & & 0.01 & 0.01 & & & & & & & & & & & & \\
\hline CM-A45 & & & & & & & & & 0.01 & & & & & & & & 0.01 & & & & \\
\hline CM-A46 & & & & & & & 0.04 & 0.01 & & & & & & & & & 0.01 & & & & \\
\hline CM-A55 & & & & & & & & 0.01 & & & & & & & & & & & & & \\
\hline $\begin{array}{l}\text { Hetero- } \\
\text { plasmy }\end{array}$ & & & & & & & & 0.01 & & & & & & & & & & & & & \\
\hline
\end{tabular}

sites can therefore be accurately assessed by satellite tracking, and we are confident that our definition of the foraging areas, and hence migration distance, for turtles was accurate. Distances between NPs and ssFGs, and those between NPs and the lsFG consisting of older and larger turtles were then compared. Although some large animals can also be found at ssFGs and were consequently pooled in the analysis, the overall comparison is relevant because we know that adults are certainly able to home to natal areas to breed (Bowen \& Karl, 2007) and larger juveniles and adults in the lsFG may therefore forage closer to breeding areas in accordance to the 'closest-tohome' hypothesis.
Geographical coordinates and distances were obtained using Google Earth v. 4.3. The average distances travelled by individuals were calculated in two ways. First, the average distance travelled by individuals from each NP was estimated using the 'nesting population-centric' MSA results. Second, the average distances travelled by individuals that are feeding in a particular FG was calculated, but using 'foraging groupcentric' MSA results. This provided distance data for all ssFGs and a single lsFG. Published data of satellite transmitters or mark-recapture studies provided further distance estimates for other adult-sized FGs. In satellite tracking studies turtles are equipped with transmitters that relay data via the Argos 
satellite system, which provides locations with a typical accuracy of a few kilometres (Bradshaw et al., 2007). However, multiple locations are obtained, and so despite the poor accuracy of individual locations the overall position of the FGs is relatively well resolved. For Costa Rican adult turtles, the average of direct distances for 10 individuals (Troëng et al., 2005) was $512 \mathrm{~km}$ (range 130-1250 km). For Ascension turtles, we used satellite tracking data for 10 of 11 tracked turtles (Luschi et al., 1998; Hays et al., 2002). After discarding data for one turtle due to its short tracking duration (Luschi et al., 1998), the average direct distance was $2455 \mathrm{~km}$ (range 1793-3025 km). For Guinea Bissau, the average direct distance of $1016 \mathrm{~km}$ was estimated from the reported foraging location (Godley et al., 2003b). Finally, the average direct distance for the Bioko population was $548 \mathrm{~km}(130-1250 \mathrm{~km})$ based on mark-recapture results (Tomas et al., 2001).

\section{Lagrangian drifter data}

Data on satellite-tracked buoys were obtained from the National Oceanic and Atmospheric Administration (NOAA, USA). These buoys are released throughout the year. To minimize the impact of wind on the trajectories, either a $25-\mathrm{m}^{2}$ window shade drogue or a 50-kg weight are attached to each buoy via a long (up to $100 \mathrm{~m}$ ) rope and chain tether. The locations of these buoys are determined using various satellite tracking systems (RAMS, Argos, EOLE) which provided several position fixes per day with a high degree of accuracy (0.1-2.0 km), and the data are reported on the NOAA web site (http://www.aoml.noaa.gov/). Buoy trajectory data have been used to estimate the age of juvenile loggerheads by estimating their transatlantic drift time from the eastern USA (Hays \& Marsh, 1997). Here we searched the data for satellite-tracked near surface (0-100 $\mathrm{m}$ ) buoys that have drifted near the main Atlantic green turtle NPs between 1979 to the present, selecting a particular window with an amplitude of $\pm 1^{\circ}$ for longitude and latitude.

\section{RESULTS}

Population genetic structure of nesting populations and foraging groups

FindModel showed that the best model of nucleotide substitution was the Tamura-Nei model (Tamura \& Nei, 1993). The global test of differentiation among Atlantic and Mediterranean NPs revealed significant differences (exact $\mathrm{P}<0.001)$. Four spatially coherent clusters $(\mathrm{K})$ were identified with Geneland analysis: the first were the central western Atlantic NPs (Aves and Surinam; CWA cluster); the second was unequivocally composed of the samples from the Mediterranean Sea (Cyprus; MED cluster); the third consisted of the north-western Atlantic NPs (Florida, Mexico and Costa Rica; NWA cluster); and the fourth included the south-western and eastern Atlantic populations together (Rocas Atoll, Trindade Island, Ascension Island, Guinea Bissau, Bioko and
Table 3 Results of pairwise comparisons of small-sized neritic foraging groups of green turtles (Chelonia mydas). Abbreviations for each site are defined in Fig. 1.

\begin{tabular}{llllllllll}
\hline & \multicolumn{2}{l}{ CV } & FL & NC & BB & BH & RA & UB & AF \\
\hline CV & - & 0.768 & 0.688 & 0.291 & 0.632 & 0.069 & 0.199 & 0.063 \\
FL & $<0.001$ & - & 0.033 & 0.324 & 0.051 & 0.829 & 0.846 & 0.640 \\
NC & $<0.001$ & 0.011 & - & 0.226 & 0.046 & 0.712 & 0.757 & 0.560 \\
BB & $<0.001$ & $<0.001$ & $<0.001$ & - & 0.178 & 0.301 & 0.413 & 0.168 \\
BH & $<0.001$ & $<0.001$ & $<0.001$ & $<0.001$ & - & 0.657 & 0.727 & 0.514 \\
RA & 0.019 & $<0.001$ & $<0.001$ & $<0.001$ & $<0.001$ & - & 0.016 & 0.043 \\
UB & $<0.001$ & $<0.001$ & $<0.001$ & $<0.001$ & $<0.001$ & 0.106 & - & 0.077 \\
AF & 0.090 & $<0.001$ & $<0.001$ & $<0.001$ & $<0.001$ & 0.196 & $<0.001$ & - \\
\hline
\end{tabular}

$\mathrm{U}_{\mathrm{ST}}$ values are shown above the diagonal, and the P-values for exact tests of differentiation, as derived from observed haplotype frequencies, are shown below the diagonal. Values not significant at 0.05 are in bold.

São Tomé and Príncipe; SWEA cluster). The Atlantic clusters correspond to the three broad regions of connectivity identified by Bolker et al. (2007). AMOVA showed that the great majority of the variation derived from differences among the clusters (83.66\%), with only a small amount due to differences among and within NPs (1.27 and 15.07\%, respectively; $\mathrm{U}_{\mathrm{ST}}=0.849, \mathrm{P}<0.001$ ), thus corroborating the results of the Bayesian analysis.

The global test of differentiation among ssFGs was also significant (exact $P<0.001$ ), and for pairwise exact tests of differentiation there were only three non-significant comparisons (Cape Verde and Almofala exact $P=0.090$; and Rocas Atoll with Ubatuba and Almofala exact $P=0.106$ and 0.196, respectively; Table 3). However, the Bayesian cluster analysis applied to ssFGs failed to produce any consistent clustering. AMOVA found that the variation was equally derived from differences within (49.32\%) and among the ssFGs (50.68\%; $\mathrm{U}_{\mathrm{ST}}=0.507, \mathrm{P}<0.001$ ), which is consistent with the Bayesian analysis not being able to find clear clusters among the ssFGs.

\section{Genetic connectivity among nesting populations and foraging groups}

Generally, the 'foraging group-centric' MSA, that estimates the origin of juveniles that are feeding in a particular Atlantic ssFG, are broadly consistent with results found by Bolker et al. (2007) (Fig. 2, Table 4). The key novel finding of our study is that the individuals that feed in Cape Verde were estimated to be from NPs on both sides of the Atlantic as well as the middle of the ocean (e.g. Surinam, Ascension and Guinea Bissau; Fig. 2, Table 4), with this being the first report from a 'manyto-many' MSA of a substantial (>30\%) contribution of a rookery on the coast of South America to a FG on the coast of West Africa.

In contrast, individuals from the Mediterranean NPs (Cyprus) were rare or absent in the Atlantic FGs studied, with contributions to these areas always less than $1 \%$. Consequently, we excluded the Cyprus NP from the 'nesting population- 


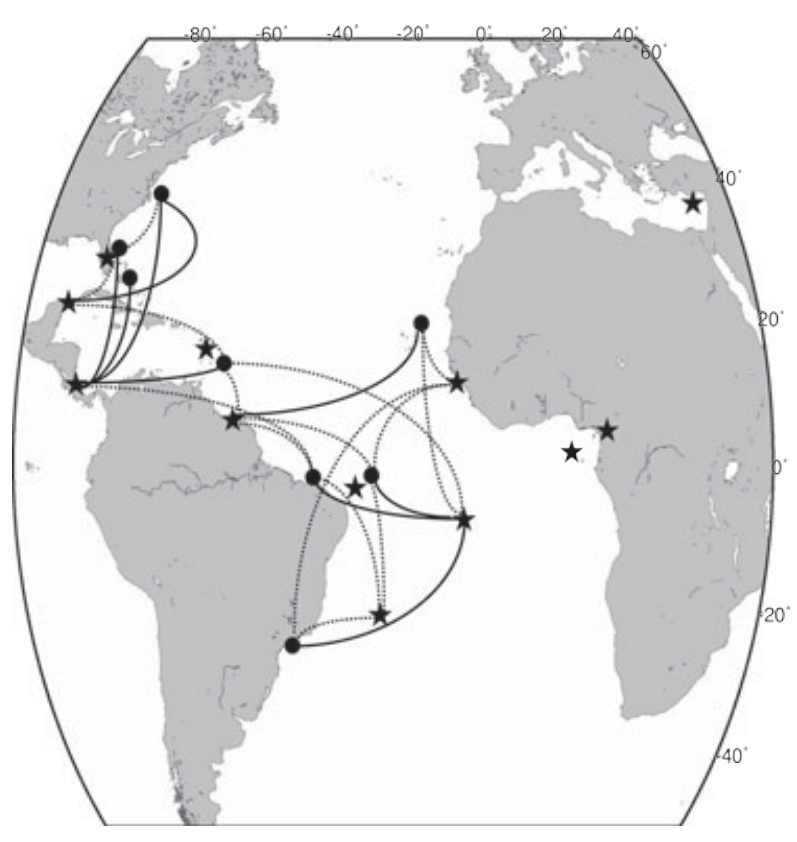

Figure 2 Major genetic connectivity between small-sized foraging groups and nesting populations of green turtles (Chelonia mydas). Based on the results of the foraging group-centric mixed stock analysis, black solid lines indicate contributions greater than $30 \%$ and dashed lines show connections between 10 and 30\%. Other contributions $<10 \%$ are excluded for clarity. Lines were curved to increase clarity and are not meant to indicate routes of travel. Stars and circles show nesting populations and foraging grounds, respectively. For names of each location see Fig. 1.

centric' MSA analysis. We also excluded the Nicaraguan samples because they represent a lsFG rather than a ssFG (see relatively large body sizes in Table 1 ). The 'nesting populationcentric' MSA showed that small green turtle juveniles from one NP generally end up in many widely dispersed ssFGs (Table 5); again, broadly consistent with Bolker et al. (2007). There was an overall negative correlation between distance from the $\mathrm{NP}$ to the ssFG and the proportion of individuals of that NP that feed in this ssFG $(r=) 0.462, P<0.001)$. However, this correlation was not always evident when analysing each cluster (CWA cluster: $r=$ ) 0.165, $P=0.543$; NWA cluster: $r=$ )0.732, $\quad P<0.001$; and SWEA cluster: $\quad r=$ ) 0.426, $P=0.003$; Table 5). This corresponds with the observation by Bolker et al. (2007) that the 'closest-to-home' pattern did not always apply within regions.

\section{Distances travelled by small juveniles and adults}

We estimated the average distance travelled by individuals from a particular NP to reach their ssFGs using 'nesting population-centric' MSA data. The comparison with four NPs with tagging or tracking data for adults (Costa Rica, Ascension, Guinea Bissau and Bioko) revealed that in all cases adults were foraging closer to their NPs than were small juveniles (Table 6). Furthermore, the average distance travelled by individuals of a particular feeding aggregation were found to
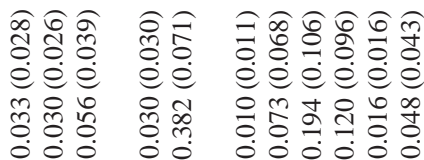

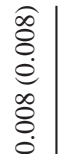
产

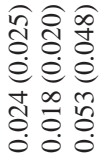

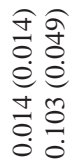

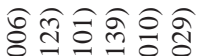

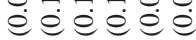

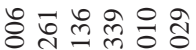

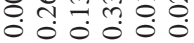

웡웡

@워 $\stackrel{0}{\varrho}$

㝵

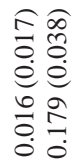

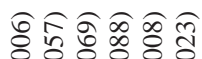

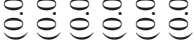

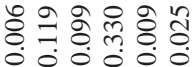

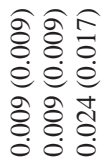

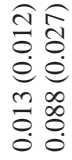

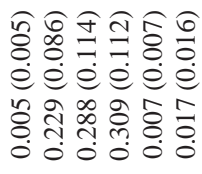

융 శ్

$\stackrel{\circ}{\ominus} \stackrel{\dot{0}}{0}$

그 옹

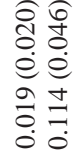

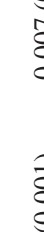

的

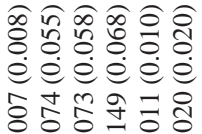

全全全昌

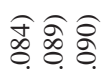

@월

ํํำ

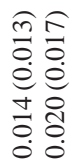

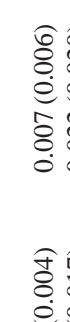

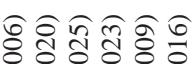

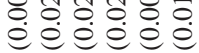

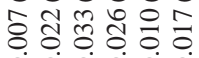

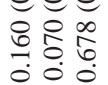

$\begin{array}{ll}\infty & 0 \\ 8 & 0 \\ 0 & 0 \\ 0 & 0\end{array}$

녕녕녕영

o

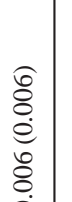
远要

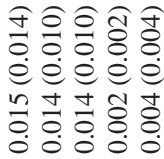

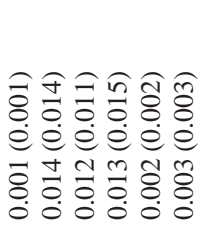

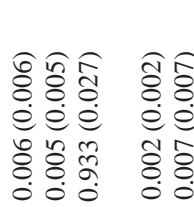

\section{\&
0
0
$\vdots$
$\vdots$
$\vdots$
0}




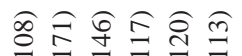

é

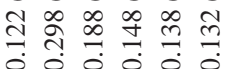

สู ิี ชิ

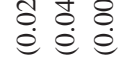

ㄴํㅇ ㅇํㅇ

สิ สิ

ज्:

ले

Table 6 Comparison of average distances travelled by the small juveniles and adults of each nesting population of green turtles (Chelonia mydas). Small juvenile distances were calculated using the results of the 'nesting population-centric' mixed stock analysis. Adult distances were obtained from published satellite transmitter and mark-recapture studies.

\begin{tabular}{llc}
\hline & \multicolumn{2}{l}{ Distance travelled (km) } \\
\cline { 2 - 3 } Nesting population & Juveniles & Adults \\
\hline Florida & 1575 & - \\
Mexico & 2063 & - \\
Costa Rica & 1435 & 512 \\
Aves & 2683 & - \\
Surinam & 2608 & - \\
Rocas Atoll & 2812 & - \\
Trindade & 2084 & - \\
Ascension & 3055 & 2455 \\
Guinea Bissau & 3360 & 1016 \\
Bioko & 6067 & 548 \\
Sâo Tomé and Príncipe & 5793 & - \\
Mean & 3048 & 1133 \\
SD & 1543 & 911 \\
\hline
\end{tabular}

be smaller for the single lsFG for which genetic data were available (Nicaragua FG, $722 \mathrm{~km}$ ) than for the rest of the ssFGs (average distance 2919 km; range 2007-3801 km). Perhaps it is more relevant to compare Nicaragua with nearby ssFGs, as these may recruit from similar NPs. For these, average distances were still greater (Florida 2080 km, North Carolina 2811 km, Bahamas 2007 km, Barbados 3340 km). All these results must be taken with some caution as they are based on comparisons with a single lsFG sampled for genetic data, and with distance data for other large-sized turtle foraging groups based on non-genetic approaches. On the other hand, all comparisons were consistent in that average distances away from natal locations were always less for FGs consisting of larger-sized turtles.

\section{Lagrangian drifter data}

Finally, we looked at observations of drift trajectories of released buoys to assess if drift is likely between NPs and ssFGs. Eleven buoys released close to NPs in the Atlantic (Fig. 3a,b) indicated that the presence of turtles at the various ssFGs could be achieved by passive drift (see Appendix S1 in Supporting Information). For example, Buoy 1 (Fig. 3a) released close to Surinam and Aves passed the Bahamas, Barbados and Florida, drifting with the strong North Atlantic Gyre. This is consistent with dispersal from Surinam and Aves to Barbados and the Bahamas, and with the high proportions of juveniles from Florida in the Florida and North Carolina ssFGs. Interestingly, the buoy then swung eastwards, crossed the Atlantic and then drifted southwards, with its final trajectory heading towards Cape Verde. This is consistent with the genetic finding that large proportions of juveniles from Surinam (0.246, SD 0.082) 

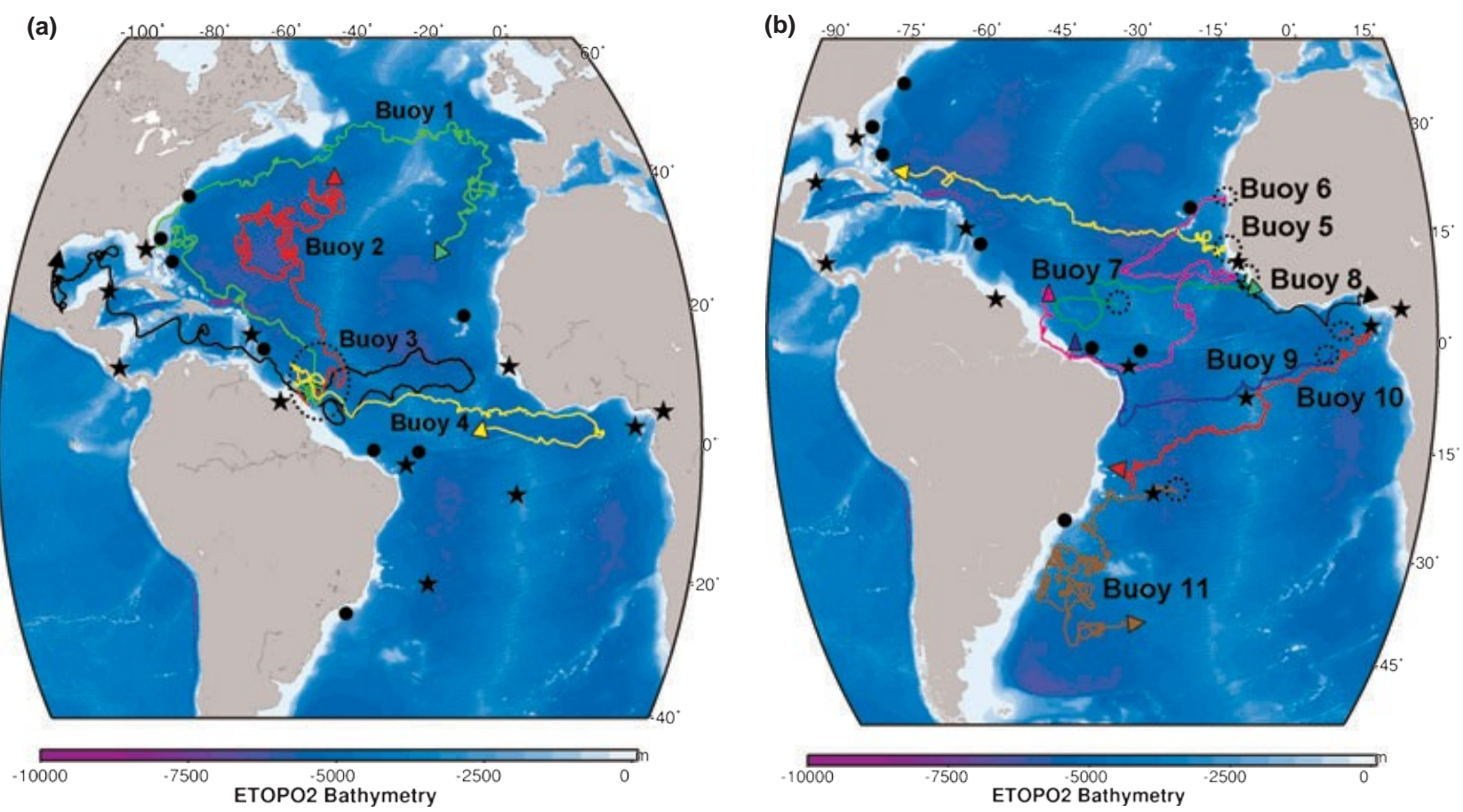

Figure 3 Map (Mollweide projection) of trajectories for buoys released in the vicinity of green turtle (Chelonia mydas) nesting populations. Stars and circles show the location of nesting populations and foraging grounds, respectively. Dotted circles show the release area for buoys. Triangles mark the end point for each trajectory. (a) Four buoys released near the central western Atlantic (CWA) and north-western Atlantic (NWA) nesting populations. The drift times and release location for the buoys were 1395 days, $50^{\circ} 41 \mathrm{c} \mathrm{W}$ and $5^{\circ} 31 \mathrm{c} \mathrm{N}$ (Buoy 1 );

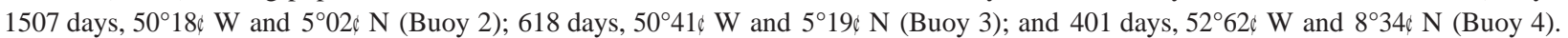

(b) Seven buoys released in the vicinity of the south-western and eastern Atlantic (SWEA) cluster. The drift times and release locations for the buoys were 564 days, $17^{\circ} 75 \mathrm{c} \mathrm{W}$ and $11^{\circ} 89 \mathrm{c} \mathrm{N}$ (Buoy 5); 494 days, $17^{\circ} 01 \mathrm{c} \mathrm{W}$ and $19^{\circ} 47 \mathrm{c} \mathrm{N}$ (Buoy 6); $236 \mathrm{days,} 35^{\circ} 14 \mathrm{c} \mathrm{W}$ and $4^{\circ} 78 \mathrm{c} \mathrm{N}$

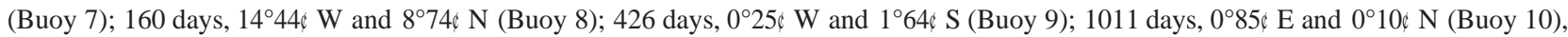
and 1235 days, $25^{\circ} 00 \mathrm{CW}$ and $20^{\circ} 01 \mathrm{c}$ S (Buoy 11). See also Appendix S1 in Supporting Information.

and Aves (0.130, SD 0.112) reached Cape Verde, and also with the surprisingly large proportion of the Cape Verde aggregation consisting of Surinam turtles (0.382, SD 0.071). The buoy took 1395 days (3.8 years) to make this journey, well within the 3-5-year period that small juveniles would typically spend in the pelagic developmental phase.

Another interesting transatlantic route was displayed by Buoys 3 and 4 (Fig. 3a), which were released close to Surinam and drifted east reaching the African coastline. This showed that turtles from Surinam could reach Cape Verde following an equatorial trajectory. These buoys then turned around and were transported back in the opposite direction, towards South America. Buoys 5 (released near Guinea Bissau) and 6 (released near Cape Verde) (Fig. 3b) also showed transatlantic transport in this direction, and demonstrated how turtles from African sites could reach locations such as the Bahamas, Rocas Atoll and Almofala. Not all drifters were transported across the Atlantic. Some travelled to relatively close locations (Buoys 8 and 11), and some had circuitous routes that kept them in the same area (Buoys 2 and 11).

\section{DISCUSSION}

Dispersal allows exploitation of spatially and/or temporally variable resources and is also an effective means of attaining different resources at different life stages. Our study extends the current understanding of the early developmental stages of green turtles at a period when they shift from pelagic to benthic habitats.

\section{Population genetic structure of nesting populations and foraging groups}

As expected, there was significant population genetic structure among NPs, consistent with the hypothesis of homing to natal breeding locations by adults. Bolker et al. (2007) suggested three main Atlantic regions where the FGs were primarily recruited from NPs within the regions connectivity thus being influenced by spatial proximity. Here, we confirm the genetic similarity of the NPs within these regions. Our observation of a broad correlation between geographical distances between NPs and ssFGs and the proportion of small juveniles that had travelled to the ssFGs also supports the idea that connectivity is generally stronger for closer locations. However, we found that this correlation did not always apply within regions. Indeed, the genetic structure for ssFGs was far less defined than for NPs. 
The genetic differences among ssFGs based on the exact test of population differentiation confirmed the non-random distribution of animals among these locations, as has been shown in previous studies (Luke et al., 2004; Bass et al., 2006; Bolker et al., 2007; Naro-Maciel et al., 2007). However, these could not be grouped into distinct genetic clusters. The lack of genetic similarity between most neigh- bouring ssFGs (Table 3) indicates that NP sources of recruit- ment for each FG are quite variable, resulting in high diversity both within and between the ssFGs. AMOVA showed lower levels of population structure

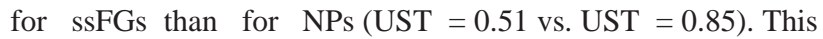
pattern is probably a result of the 'weak migratory connectivity' typical for the green turtle (Bolker et al., 2007), where there are no strong links between individual foraging grounds and individual natal populations and individuals from the same natal population disperse to many foraging locations (Webster et al., 2002).

Genetic connectivity among nesting populations and foraging grounds

Overall, the key patterns of connectivity were broadly similar to those found by Bolker et al. (2007), even though there were differences in datasets used by the two studies. The 'many-tomany' MSA results therefore appear robust, but one should still be cautious when interpreting the results, since point estimates had large SDs, and not all NPs and ssFGs have necessarily been adequately sampled. The 'nesting population- centric' MSA revealed higher SD values for smaller populations ( $\mathrm{n}<$ 1000 compared with $\mathrm{n}>1000$; Mann-Whitney U-test, $\mathrm{P}=$ 0.021), showing that there is less confidence in estimating where individuals from very small rookeries end up [coefficient of variation $(\mathrm{CV})=$ standard deviation/mean; average $\mathrm{CV}=0.881$ and 0.751 for populations of smaller and larger sizes, respectively].

As previously observed (Bolker et al., 2007), we also find regional geographical association among NPs and ssFGs in some cases, such as those of the north-western Atlantic, whereas juveniles of other NPs distribute to areas that are more widely separated (Fig. 2, Table 5). Previous studies have interpreted this connectivity between NPs and ssFGs as evidence for juvenile natal homing (Bolker et al., 2007), where turtles prefer to settle in foraging areas close to natal locations ('closest-to-home' hypothesis). There are also other factors that may influence the distribution of small juvenile turtles, such as passive drift with ocean currents (Hughes, 1974; Carr

\& Meylan, 1980; Luke et al., 2004; Bass et al., 2006; Bolker et al., 2007; Naro-Maciel et al., 2007). If an object is drifting, it is more likely to first encounter locations closer to the release point than further away, so an association between distance and the probability of drifting to a location may be expected. Juvenile turtles may in fact by-pass the closest suitable neritic habitats during the pelagic phase of their life cycle, and end up in the vicinity of locations further away, depending on their pattern of drift. Several authors have suggested the importance of currents in marine turtle life cycles, and considered that these played the major role in determining the dispersal of hatchlings and early juveniles (Hughes, 1974; Carr \& Meylan organisms, swimming ability and the strength of waves and 1760 currents may determine distribution and choice of habitat (e.g. Fulton \& Bellwood, 2004). Bolker et al. (2007) suggested that future green turtle MSA studies should also consider the impact of ocean currents. Here, we used Lagrangian drifter data to show that there were buoys released in the Atlantic that had drifted between many of the NPs and ssFGs linked by genetic connectivity (Fig. 3), thereby confirming that transport by ocean currents between these locations is possible. Most importantly, Lagrangian drifter data provided independent evidence that transatlantic transport is feasible.

\section{New evidence for transport across the Atlantic}

Evidence for transatlantic movement of small juvenile green turtles from Africa to South America has previously been provided by genetic data, for example demonstrating that the Guinea Bissau NP is an important contributor to foraging assemblages around the Brazilian coast (north-east Brazil, Bolker et al., 2007; Rocas Atoll and Ubatuba, this study). Surface drifters released off the West African coast show that drift towards Brazil is possible (Fig. 3b), supporting the genetic evidence. The major novel finding of this study is genetic evidence for significant dispersal of small juvenile green turtles in the opposite direction, and that transport across the North Atlantic is likely. This is an important finding, as it finally confirms that transatlantic travel in either direction is possible and indeed commonly achieved by small juvenile turtles, extending the conclusions of Bass et al. (2006), Bolker et al. (2007) and Reich et al. (2007). Our finding is based on new genetic data for a juvenile FG on the West African coast (Cape Verde) that had not been previously studied. A large proportion of the Cape Verde FG (38\%) was estimated by 'many-tomany' MSA of mtDNA data to have originated from Surinam in South America. The analysis also indicated that the Cape Verde contingent represents a large proportion of the Surinam population (25\%). Bolker et al. (2007) also included a West African FG (Corisco Bay) in their MSA. Many-to-one analysis showed a strong contribution from small north-east Brazilian rookeries ( $n=125)$, indicating that eastwards transport across the Atlantic is likely - however, this was no longer the case with the more sophisticated 'many-to-many' analysis, which takes population sizes into account (Fig. 2 of Bolker et al., 2007). In contrast, the Surinam NP is large $(n=1814)$ and the 'many-to-many' analysis of this study finally provides firm evidence for transatlantic migration in an easterly direction. The trajectory of Buoy 1 (Fig. 3a) encapsulates one possible scenario of transatlantic transport from the coast of Surinam to the coast of West Africa. After being released close to Surinam, the buoy drifted north with the Gulf Stream, then east with the North Atlantic Drift, then south with the Canary Current. How typical is this transport trajectory? Along the east coast of North America the Gulf Stream is a significant current, and the conventional view of it is as a well-defined transport system and a strong barrier to near-surface crossbeing transported towards the Grand Banks by the Gulf Stream and taken further north as would be expected, surface drifters in the Gulf Stream off the east coast of the USA are observed to almost always end up in the Sargasso Sea (T. 
Rossby, University of Rhode Island, pers. comm.). In fact, there is virtually no movement of surface drifters between North Atlantic subtropical and subpolar gyres (Brambilla \& Talley,

2006). Instead, surface drifters have a tendency for expulsion out of the Gulf Stream to the south. A recent study of data from over a thousand drifters indicates that southward exits are aggregated in specific locations off the coast of New England and Newfoundland, and indicate the most likely mechanism to be wind-driven Ekman drift (T. Rossby, pers. comm.). Thus, small juvenile turtles that have entered the Gulf Stream are unlikely to be taken far north into subpolar regions. Rather they are more likely to be ejected southwards into the Sargasso Sea. Once there, it is possible to drift with the North Atlantic Oscillation and cross the Atlantic in a few years. For example, particle-tracking models for eels (Anguilla anguilla) estimate an average migration duration of less than 2 years to cross the North Atlantic from the Sargasso Sea (Kettle \& Haines, 2006; Bonhommeau et al., 2009). The entire journey of Buoy 1 from Surinam to the West coast of Africa (Fig. 3a) took 1395 days (3.8 years). Another possible route across the Atlantic is via the equator. The trajectories of Buoys 3 and 4 (Fig. 3a) shows transatlantic transport from Surinam to the eastern Atlantic coasts with the Equatorial Counter Current. Notably, this demonstrates that drift in the opposite direction, from the African coasts to the western Atlantic, is also possible with the South Equatorial Current.

Lagrangian drifter data and particle tracking models therefore confirm that marine organisms can be transported across the Atlantic Ocean by passive means, and that the journey time can be within the estimated oceanic developmental phase of green turtles. Drift with ocean currents is not the only factor determining the post-natal dispersal of small juvenile green turtles, but it may be an important facilitator for long-distance transoceanic journeys.

Distances travelled by small juveniles compared with those of larger-sized juveniles and adults

According to the 'closest-to-home' hypothesis, turtles tend to settle in foraging areas close to their natal origin. In all cases, we found that larger turtles foraged closer to their NPs than did smaller juveniles. This implies that even if turtles initially recruit to neritic locations far away, they may eventually move closer to 'home'. Lagrangian drifter data (Fig. 3, Appendix S1) showed that most of the FGs indicated by 'many-to-many' analysis as being connected to particular natal locations can indeed be reached by drift, even for transatlantic locations. We do not suggest that turtles only get there by drift, but rather that ocean currents may play a role in explaining how turtles reach distant foraging locations. We refine the 'closest-tohome' hypothesis in suggesting that while it is true in general, and particularly for certain NPs (e.g. the NWA cluster), for cases where some juveniles may be transported to far-flung locations by external factors such as strong currents (e.g. the CWA and SWEA clusters) it seems that the turtles may still try to return closer to 'home' via further developmental migrations when they become larger. This would explain the observation first made by Bolker et al. (2007) that the 'closest-to-home' hypothesis did not always apply within regions of connectivity. We caution though that our attempt to compare the average distances between NPs and FGs for smallversus large-sized turtles remains tentative. Future studies could improve on this, with further genetic sampling of lsFGs and by obtaining individual size measurements linked with genetic information when sampling ssFGs and lsFGs.

\section{Comparison with other sea turtle species: size and navigation}

Loggerhead (Caretta caretta) and green turtles diverged more than 50 million years ago (Bowen et al., 1993; Naro-Maciel et al., 2008); however, there may still be similarities in their biology. During the pelagic stage, hatchling loggerheads exhibit directional swimming in relation to the Earth's magnetic field (Lohmann et al., 2001, 2008a). However, juvenile sizes may be a limitation on swimming capacity (Revelles et al., 2007; Eckert et al., 2008; Monzón-Argüello et al., 2009). The pelagic stage of green turtles is shorter than for loggerheads (Bjorndal et al., 2000; Reich et al., 2007), so it is not unreasonable to suspect that active navigation is constrained for the smallersized green sea turtles during their pelagic stage.

The population genetic structure of loggerhead turtles becomes progressively more distinct as they advance in age and development. The pelagic juvenile aggregations have no genetic structure (Bolten et al., 1998; Bowen et al., 2004; Bowen \& Karl, 2007), although there could be spatial variation in their composition (Monzón-Argüello et al., 2009). More advanced benthic juveniles migrate from oceanic habitat to coastal habitat in the vicinity of their natal rookery, showing juvenile natal homing behaviour (Maffucci et al., 2006). MSA of benthic juvenile FGs showed significant mtDNA haplotype frequency shift and a significant correlation between haplotype frequencies in coastal feeding populations and haplotype composition of adjacent NPs. Thus, as juveniles grow they exhibit more natal homing behaviour (Bowen et al., 2004; Bowen \& Karl, 2007). However, other species may show different patterns. For the hawksbill sea turtle (Eretmochelys imbricata) in Puerto Rico, new recruits as well as resident juveniles appeared to be largely composed of individuals originating from other rookeries, showing that recruitment into feeding areas appears to be largely influenced by oceanic mixing during the pelagic stage (Velez-Zuazo et al., 2008).

\section{CONCLUSIONS}

We extend the scenario initially proposed by Carr \& Meylan (1980) for green turtles in the Atlantic Ocean. Small early 
juveniles from the same NP reach many different foraging locations, and dispersal may in some cases be affected by strong ocean currents, because at the pelagic stage they may be too small to swim effectively against the current, although it is possible that they maintain their position using navigational senses. Many will indeed recruit to locations close to their natal beach, perhaps aided by navigation senses, but a proportion will travel across the Atlantic, perhaps facilitated by strong prevailing currents. Transatlantic transport can occur in either direction. If the locations reached by the small juveniles represent a suitable habitat for development, they will leave the pelagic habitat to become benthic feeders and become larger (data on body sizes show turtles in some of the ssFGs to be quite large; Table 1). Advanced juveniles attaining larger sizes may then swim more effectively against currents and use their navigation and homing abilities to find their way towards foraging areas that are closer to their natal NPs. As adults, turtles of nearly all species migrate intermittently to and from their FGs to their nesting beaches (Miller, 1997; Bowen \& Karl, 2007), using their homing and sensory abilities to navigate to their final destination (Luschi et al., 2001; Hays et al., 2002; Lohmann et al., 2008a,b). Finally, it is important to note that the switch from pelagic to benthic habitat is not immutable, and both advanced juveniles and adults can switch back to pelagic feeding, as has been shown in other species (Hatase et al., 2002; Witzell et al., 2002; Hawkes et al., 2006; McClellan \& Read, 2007). Hence, there must be some degree of flexibility in feeding and in dispersal behaviour.

\section{FUTURE DIRECTIONS}

Continuing advances in the development of new markers, sequencing methods and increasingly more sophisticated analytical approaches (Riddle et al., 2008) mean that sea turtle phylogeography and population genetics should continue to progress. Currently, the MSA of green turtles is based on a single linked marker (mtDNA sequences), but in future multilocus genotypes could be useful (Lee, 2008). Furthermore, we recommend expanding the genetic analysis throughout Macaronesia, the western coast of Africa and the Mediterranean Sea. This will complete the necessary framework for a fuller understanding of the life history of green turtles in the Atlantic. We know that the current dataset does not include all FGs because of the high proportion juveniles of some breeding populations dispersing to still unknown destinations (Table 5). A further direction that promises to be fruitful would be the inclusion of oceanographic particle tracking models (Hays \& Marsh, 1997) in attempting to predict more accurately the dispersal of small juvenile turtles. Particle tracking models are becoming more biologically realistic, allowing the incorporation of parameters such as behaviour and mortality (Kettle \& Haines, 2006; Bonhommeau et al., 2009). Such investigation would require sophisticated modelling that is beyond the scope of the current study, but this may be the future route towards delivering accurate predictions concerning the relative importance of various ssFGs for particular NPs.

\section{ACKNOWLEDGEMENTS}

We thank G. Évora, E. Abella, P. Sanz, the monitors and volunteers of Cabo Verde Natura 2000 and students of the Instituto Superior de Engenharia e Ciências do Mar (ISECMAR) for their contributions to sampling and field collection. We also thank N. Varo for helpful comments on earlier versions on this manuscript. Ben Bolker advised on use of the many-tomany mixed stock analysis and Tom Rossby informed us of new work on Lagrangian drift patterns in the North Atlantic. We are grateful to the Cabo Verde Ministry of the Environment (General Direction for the Environment), INDP (National Fisheries Institution), the Canary Islands government, Instituto Canario de Ciencias Marinas, Estación Biológica de Doñana and Fundación BBVA for helping with the field and laboratory equipment. We would also like to thank Swansea University, the European Science Foundation (ConGen) and the Journal Club of Estación Biológica de Doñana. C.M.A. was supported by a PhD grant from the Canary Islands government.

\section{REFERENCES}

Abreu-Grobois, F., Horrocks, J., Formia, A., LeRoux, R., VelezZuazo, X., Dutton, P., Soares, L., Meylan, P. \& Browne, D. (2006) New mtDNA Dloop primers which work for a variety of marine turtle species may increase the resolution capacity of mixed stock analysis. 26th Annual Symposium on Sea Turtle Biology and Conservation, Crete, Greece, 2-6 April 2006 (ed. by M. Frick, A. Panagopoulou, A.F. Rees and K. Williams), p. 179. Available at: http://www.iucn-mtsg.org/ genetics/meth/primers/abreu_grobois_etal_new_dloop_primers.pdf.

Balazs, G.H. (1982) Growth rates of immature green turtles in the Hawaiian archipelago. Biology and conservation of sea turtles (ed. by K.A. Bjorndal), pp. 117-125. Smithsonian Institution Press, Washington, DC.

Bass, A.L. \& Witzell, W.N. (2000) Demographic composition of immature green turtles (Chelonia mydas) from the east central Florida coast: evidence from mtDNA markers. Herpetologica, 56, 357-367.

Bass, A.L., Lagueux, C.J. \& Bowen, B.W. (1998) Origin of green turtles, Chelonia mydas, at "Sleeping Rocks" off the northeast coast of Nicaragua. Copeia, 1998, 1064-1069.

Bass, A.L., Epperly, S.P. \& Braun-McNeill, J. (2006) Green turtle (Chelonia mydas) foraging and nesting aggregations in the Caribbean and Atlantic: impact of currents and behavior on dispersal. Journal of Heredity, 97, 346-354.

Bellini, C., Marcovaldi, M.A., Sanches, T.M., Grossman, A. \& Sales, G. (1995) Atol das Rocas biological reserve: second largest Chelonia rookery in Brazil. Marine Turtle Newsletter, 72, 1-2.

Bjorndal, K.A. (1980) Nutrition and grazing behavior of the green turtle Chelonia mydas. Marine Biology, 56, 147-154. 
Bjorndal, K.A. \& Bolten, A.B. (2008) Annual variation in source contributions to a mixed stock: implications for quantifying connectivity. Molecular Ecology, 17, 2185-2193.

Bjorndal, K.A., Bolten, A.B. \& Martins, H.R. (2000) Somatic growth model of juvenile loggerhead sea turtles Caretta caretta: duration of pelagic stage. Marine Ecology-Progress Series, 202, 265-272.

Bjorndal, K.A., Bolten, A.B. \& Troëng, S. (2005) Population structure and genetic diversity in green turtles nesting at Tortuguero, Costa Rica, based on mitochondrial DNA control region sequences. Marine Biology, 147, 1449-1457.

Bjorndal, K.A., Bolten, A.B., Moreira, L., Bellini, C. \& Marcovaldi, M.A. (2006) Population structure and diversity of Brazilian green turtle rookeries based on mitochondrial DNA sequences. Chelonian Conservation and Biology, 5, 262-268.

Bolker, B.M., Okuyama, T., Bjorndal, K.A. \& Bolten, A.B. (2007) Incorporating multiple mixed stocks in mixed stock analysis: 'many-to-many' analyses. Molecular Ecology, 16, 685-695.

Bolten, A.B. (2003) Variation in sea turtle life history patterns: neritic vs. oceanic developmental stages. The biology of sea (ed. by P.L. Lutz, J.A. Musick and J. Wyneken), pp. 243-257. CRC Press, Boca Raton, FL.

Bolten, A.B., Bjorndal, K.A., Martins, H.R., Dellinger, T., Biscoito, M.J., Encalada, S.E. \& Bowen, B.W. (1998) Transatlantic developmental migrations of loggerhead sea turtles demonstrated by mtDNA sequence analysis. Ecological Applications, 8, 1-7.

Bonhommeau, S., Le Pape, O., Gascuel, D., Blanke, B., Treguier, A.M., Grima, N., Vermard, Y., Castonguay, M. \& Rivot, E. (2009) Estimates of the mortality and the duration of the trans-Atlantic migration of European eel Anguilla anguilla leptocephali using a particle tracking model. Journal of Fish Biology, 74, 1891-1914.

Bowen, B.W. \& Karl, S.A. (2007) Population genetics and phylogeography of sea turtles. Molecular Ecology, 16, 48864907.

Bowen, B.W., Meylan, A.B., Ross, J.P., Limpus, C.J., Balazs, G.H. \& Avise, J.C. (1992) Global population structure and natural history of the green turtle (Chelonia mydas) in terms of matriarchal phylogeny. Evolution, 46, 865-881.

Bowen, B.W., Nelson, W.S. \& Avise, J.C. (1993) A molecular phylogeny for marine turtles: trait mapping, rate assessment, and conservation relevance. Proceedings of the National Academy of Sciences USA, 90, 5574-5577.

Bowen, B.W., Bass, A.L., Chow, S.M., Bostrom, M., Bjorndal, K.A., Bolten, A.B., Okuyama, T., Bolker, B.M., Epperly, S., Lacasella, E., Shaver, D., Dodd, M., Hopkins-Murphy, S.R., Musick, J.A., Swingle, M., Rankin-Baransky, K., Teas, W., Witzell, W.N. \& Dutton, P.H. (2004) Natal homing in juvenile loggerhead turtles (Caretta caretta). Molecular Ecology, 13, 3797-3808.

Bower, A.S., Rossby, H.T. \& Lillibridge, J.L. (1985) The Gulf Stream - barrier or blender? Journal of Physical Oceanography, $15,24-32$.
Bowler, D.E. \& Benton, T.G. (2005) Causes and consequences of animal dispersal strategies: relating individual behaviour to spatial dynamics. Biological Reviews, 80, 205-225.

Bradshaw, C.J.A., Sims, D.W. \& Hays, G.C. (2007) Measurement error causes scale-dependent threshold erosion of biological signals in animal movement data. Ecological Applications, 17, 628-638.

Brambilla, E. \& Talley, L.D. (2006) Surface drifter exchange between the North Atlantic subtropical and subpolar gyres. Journal of Geophysical Research-Oceans, 111, C07026. doi:10.1029/2005JC003146.

Carr, A. \& Meylan, A.B. (1980) Evidence of passive migration of green turtle hatchlings in Sargassum. Copeia, 1980, 366368.

Dawson, M.N. \& Hamner, W.M. (2008) A biophysical perspective on dispersal and the geography of evolution in marine and terrestrial systems. Journal of the Royal Society Interface, 5, 135-150.

Eckert, S.A., Moore, J.E., Dunn, D.C., van Buiten, R.S., Eckert, K.L. \& Halpin, P.N. (2008) Modeling loggerhead turtle movement in the Mediterranean: importance of body size and oceanography. Ecological Applications, 18, 290-308.

Encalada, S.E., Lahanas, P.N., Bjorndal, K.A., Bolten, A.B., Miyamoto, M.M. \& Bowen, B.W. (1996) Phylogeography and population structure of the Atlantic and Mediterranean green turtle Chelonia mydas: a mitochondrial DNA control region sequence assessment. Molecular Ecology, 5, 473-483.

Excoffier, L., Laval, G. \& Schneider, S. (2005) Arlequin (version 3.0): an integrated software package for population genetics data analysis. Evolutionary Bioinformatics Online, 1, 47-50.

Formia, A. (2002) Population and genetic structure of the green turtle (Chelonia mydas) in west and central Africa; implications for management and conservation. $\mathrm{PhD}$ Thesis, University of Cardiff, Cardiff, UK.

Formia, A., Godley, B.J., Dontaine, J.F. \& Bruford, M.W. (2006) Mitochondrial DNA diversity and phylogeography of endangered green turtle (Chelonia mydas) populations in Africa. Conservation Genetics, 7, 353-369.

Fulton, C.J. \& Bellwood, D.R. (2004) Wave exposure, swimming performance, and the structure of tropical and temperate reef fish assemblages. Marine Biology, 144, 429-437.

Godley, B.J., Broderick, A.C., Glen, F. \& Hays, G.C. (2003a) Post-nesting movements and submergence patterns of loggerhead marine turtles in the Mediterranean assessed by satellite tracking. Journal of Experimental Marine Biology and Ecology, 287, 119-134.

Godley, B.J., Almeida, A., Barbosa, C., Broderick, A.C., Catry, P.X., Hays, G.C. \& Indjai, B. (2003b) Using satellite telemetry to determine post-nesting migratory corridors and foraging grounds of green turtles nesting at Poilao, Guinea Bissau. Report to project donors, University of Wales Swansea, Swansea (http://www.seaturtle.org/mtrg/projects/guinea_ bissau/poilao.shtml).

Guillot, G., Mortier, F. \& Estoup, A. (2005) Geneland: a computer package for landscape genetics. Molecular Ecology Notes, 5, 712-715. 
Guillot, G., Leblois, R., Coulon, A. \& Frantz, A.C. (2009) Statistical methods in spatial genetics. Molecular Ecology, 18, 4734-4756.

Hatase, H., Takai, N., Matsuzawa, Y., Sakamoto, W., Omuta, K., Goto, K., Arai, N. \& Fujiwara, T. (2002) Size-related differences in feeding habitat use of adult female loggerhead turtles Caretta caretta around Japan determined by stable isotope analyses and satellite telemetry. Marine Ecology Progress Series, 233, 273-281.

Hawkes, L.A., Broderick, A.C., Coyne, M.S., Godfrey, M.H., Lopez-Jurado, L.F., Lopez-Suarez, P., Merino, S.E., VaroCruz, N. \& Godley, B.J. (2006) Phenotypically linked dichotomy in sea turtle foraging requires multiple conservation approaches. Current Biology, 16, 990-995.

Hays, G.C. \& Marsh, R. (1997) Estimating the age of juvenile loggerhead sea turtles in the North Atlantic. Canadian Journal of Zoology-Revue Canadienne de Zoologie, 75, 40-46.

Hays, G.C., Webb, P.I., Hayes, J.P., Priede, I.G. \& French, J. (1991) Satellite tracking of a loggerhead turtle (Caretta caretta) in the Mediterranean. Journal of the Marine Biological Association of the UK, 71, 743-746.

Hays, G.C., Luschi, P., Papi, F., del Seppia, C. \& Marsh, R. (1999) Changes in behaviour during the inter-nesting period and post-nesting migration for Ascension Island green turtles. Marine Ecology Progress Series, 189, 263-273.

Hays, G.C., Broderick, A.C., Godley, B.J., Lovell, P., Martin, C., McConnell, B.J. \& Richardson, S. (2002) Biphasal longdistance migration in green turtles. Animal Behaviour, 64, 895-898.

Hirth, H.F. (1997) Synopsis of biological data on the green turtle Chelonia mydas (Linnaeus 1758). US Fish and Wildlife Service Biological Report 97. US Fish and Wildlife Service, Washington DC.

Hughes, G.R. (1974) The sea turtles of south-east Africa. I. Status, morphology and distributions. Investigative Report 35. Oceanographic Research Institute, Durban.

Kaska, Y. (2000) Genetic structure of Mediterranean sea turtle populations. Turkish Journal of Zoology, 24, 191-197.

Kettle, A.J. \& Haines, K. (2006) How does the European eel (Anguilla anguilla) retain its population structure during its larval migration across the North Atlantic Ocean? Canadian Journal of Fisheries and Aquatic Sciences, 63, 90-106.

Lahanas, P.N., Bjorndal, K.A., Bolten, A.B., Encalada, S.E., Miyamoto, M.M., Valverde, R.A. \& Bowen, B.W. (1998) Genetic composition of a green turtle (Chelonia mydas) feeding ground population: evidence for multiple origins. Marine Biology, 130, 345-352.

Lee, P.L.M. (2008) Molecular ecology of marine turtles: new approaches and future directions. Journal of Experimental Marine Biology and Ecology, 356, 25-42.

Lohmann, K.J., Hester, J.T. \& Lohmann, C.M.F. (1999) Longdistance navigation in sea turtles. Ethology, Ecology and Evolution, 11, 1-23.

Lohmann, K.J., Cain, S.D., Dodge, S.A. \& Lohmann, C.M.F. (2001) Regional magnetic fields as navigational markers for sea turtles. Science, 294, 364-366.
Lohmann, K.J., Luschi, P. \& Hays, G.C. (2008a) Goal navigation and island-finding in sea turtles. Journal of Experimental Marine Biology and Ecology, 356, 83-95.

Lohmann, K.J., Putman, N.F. \& Lohmann, C.M.F. (2008b) Geomagnetic imprinting: A unifying hypothesis of longdistance natal homing in salmon and sea turtles. Proceedings of the National Academy of Sciences USA, 105, 19096-19101.

Luke, K., Horrocks, J.A., LeRoux, R.A. \& Dutton, P.H. (2004) Origins of green turtle (Chelonia mydas) feeding aggregations around Barbados, West Indies. Marine Biology, 144, 799-805.

Luschi, P., Hays, G.C., Del Seppia, C., Marsh, R. \& Papi, F. (1998) The navigational feats of green sea turtles migrating from Ascension Island investigated by satellite telemetry. Proceedings of the Royal Society B: Biological Sciences, 265, 2279-2284.

Luschi, P., Akesson, S., Broderick, A.C., Glen, F., Godley, B.J., Papi, F. \& Hays, G.C. (2001) Testing the navigational abilities of ocean migrants: displacement experiments on green sea turtles (Chelonia mydas). Behavioral Ecology and Sociobiology, 50, 528-534.

Maffucci, F., Kooistra, W. \& Bentiveyna, F. (2006) Natal origin of loggerhead turtles, Caretta caretta, in the neritic habitat off the Italian coasts, Central Mediterranean. Biological Conservation, 127, 183-189.

McClellan, C.M. \& Read, A.J. (2007) Complexity and variation in loggerhead sea turtle life history. Biology Letters, 3, 592-594.

Miller, J.D. (1997) Reproduction in sea turtles. The biology of sea turtles (ed. by P.L. Lutz and J.A. Musick), pp. 51-81. CRC Press, Boca Raton, FL.

Monzón-Argüello, C., Rico, C., Carreras, C., Calabuig, P., Marco, A. \& López-Jurado, L.F. (2009) Variation in spatial distribution of juvenile loggerhead turtles in the eastern Atlantic and western Mediterranean Sea. Journal of Experimental Marine Biology and Ecology, 373, 79-86.

Musick, J.A. \& Limpus, C.J. (1997) Habitat utilization and migration in juvenile sea turtles. The biology of sea turtles (ed. by P.L. Lutz and J.A. Musick), pp. 137-163. CRC Press, Boca Raton, FL.

Naro-Maciel, E., Becker, J.H., Lima, E., Marcovaldi, M.A. \& DeSalle, R. (2007) Testing dispersal hypotheses in foraging green sea turtles (Chelonia mydas) of Brazil. Journal of Heredity, 98, 29-39.

Naro-Maciel, E., Le, M., FitzSimmons, N.N. \& Amato, G. (2008) Evolutionary relationships of marine turtles: a molecular phylogeny based on nuclear and mitochondrial genes. Molecular Phylogenetics and Evolution, 49, 659-662.

Nei, M. (1987) Molecular evolutionary genetics. Columbia University Press, New York, NY.

Palumbi, S.R. (2004) Marine reserves and ocean neighborhoods: the spatial scale of marine populations and their management. Annual Review of Environment and Resources, 29, 31-68.

Pella, J. \& Masuda, M. (2001) Bayesian methods for analysis of stock mixtures from genetic characters. Fishery Bulletin, 99, 151-167. 
Putman, N.F. \& Lohmann, K.J. (2008) Compatibility of magnetic imprinting and secular variation. Current Biology, 18, R596-R597.

Raymond, M. \& Rousset, F. (1995) An exact test for population differentiation. Evolution, 49, 1280-1283.

Reich, K.J., Bjorndal, K.A. \& Bolten, A.B. (2007) The 'lost years' of green turtles: using stable isotopes to study cryptic lifestages. Biology Letters, 3, 712-714.

Revelles, M., Carreras, C., Cardona, L., Marco, A., Bentivegna, F., Castillo, J.J., de Martino, G., Mons, J.L., Smith, M.B., Rico, C., Pascual, M. \& Aguilar, A. (2007) Evidence for an asymmetrical size exchange of loggerhead sea turtles between the Mediterranean and the Atlantic through the Straits of Gibraltar. Journal of Experimental Marine Biology and Ecology, 349, 261-271.

Riddle, B.R., Dawson, M.N., Hadly, E.A., Hafner, D.J., Hickerson, M.J., Mantooth, S.J. \& Yoder, A.D. (2008) The role of molecular genetics in sculpting the future of integrative biogeography. Progress in Physical Geography, 32, 173-202.

Schofield, G., Bishop, C.M., MacLeon, G., Brown, P., Baker, M., Katselidis, K.A., Dimopoulos, P., Pantis, J.D. \& Hays, G.C. (2007) Novel GPS tracking of sea turtles as a tool for conservation management. Journal of Experimental Marine Biology and Ecology, 347, 58-68.

Schofield, G., Bishop, C.M., Katselidis, K.A., Dimopoulos, P., Pantis, J.D. \& Hays, G.C. (2009) Microhabitat selection by sea turtles in a dynamic thermal marine environment. Journal of Animal Ecology, 78, 14-21.

Seminoff, J.A. (2002) Red List status assessment: green turtle (Chelonia mydas). Marine Turtle Specialist Group, The World Conservation Union IUCN, Gland, Switzerland. http://www. iucn-mtsg.org/red_list/cm/MTSG_Chelonia_Assessment_ 26-4-2002.pdf.

Seminoff, J.A. (2004) Global status assessment: green turtle (Chelonia mydas). Marine Turtle Specialist Group, The World Conservation Union IUCN, Gland, Switzerland. http:// www.iucnmtsg.org/red_list/cm/MTSG_Chelonia_mydas_ assessment_6 expanded-format.pdf.

Spiegelhalter, D.J., Thomas, A., Best, N.G. \& Lunn, D. (2004) WinBUGS Version 2.0 Users Manual. MRC Biostatistics Unit, Cambridge. http://www.mrc-bsu.cam.ac.uk/bugs/ winbugs/manual14.pdf.

Tamura, K. \& Nei, M. (1993) Estimation of the number of substitutions in the control region of mitochondrial DNA in humans and chimpanzees. Molecular Biology and Evolution, 10, 512-526.

Tomas, J., Formia, A., Castroviejo, J. \& Raga, J.A. (2001) Postnesting movements of the green turtle, Chelonia mydas, nesting in the south of Bioko Island, Equatorial Guinea, West Africa. Marine Turtle Newsletter, 94, 3-6.

Troëng, S., Evans, D.R., Harrison, E. \& Lagueux, C.J. (2005) Migration of green turtles Chelonia mydas from Tortuguero, Costa Rica. Marine Biology, 148, 435-447.

Velez-Zuazo, X., Ramos, W.D., van Dam, R.P., Diez, C.E., Abreu-Grobois, A. \& McMillan, W.O. (2008) Dispersal, recruitment and migratory behaviour in a hawksbill sea turtle aggregation. Molecular Ecology, 17, 839-853.

Waples, R.S. \& Gaggiotti, O. (2006) What is a population? An empirical evaluation of some genetic methods for identifying the number of gene pools and their degree of connectivity. Molecular Ecology, 15, 1419-1439.

Webster, M.S., Marra, P.P., Haig, S.M., Bensch, S. \& Holmes, R.T. (2002) Links between worlds: unraveling migratory connectivity. Trends in Ecology and Evolution, 17, 76-83.

Witham, R. (1980) The lost year question in young sea turtles. American Zoologist, 20, 525-530.

Witzell, W.N., Bass, A.L., Bresette, M.J., Singewald, D.A. \& Gorham, J.C. (2002) Origin of immature loggerhead sea turtles (Caretta caretta) at Hutchinson Island, Florida: evidence from mtDNA markers. Fishery Bulletin, 100, 624631.

Zug, G.R., Balazs, G.H., Wetherall, J.A., Parker, D.M. \& Murakawa, S.K.K. (2002) Age and growth of Hawaiian green sea turtles (Chelonia mydas): an analysis based on skeletochronology. Fishery Bulletin, 100, 117-127.

\section{SUPPORTING INFORMATION}

Additional Supporting Information may be found in the online version of this article:

Appendix S1 Comparison of the trajectories of individual buoys with movements of juvenile green turtles inferred from genetic data.

As a service to our authors and readers, this journal provides supporting information supplied by the authors. Such materials are peer-reviewed and may be re-organized for online delivery, but are not copy-edited or typeset. Technical support issues arising from supporting information (other than missing files) should be addressed to the authors.

\section{BIOSKETCH}

Catalina Monzó n-Argü ello is a $\mathrm{PhD}$ candidate in the Department of Biology, University of Las Palmas de GC, Spain. Her dissertation research focuses on population structure, stock assessment and connectivity of sea turtles in the eastern Atlantic, with a special interest in applications for the ecology and conservation biology of sea turtles.

Author contributions: L.F.L.J. conceived the original idea and A.M. obtained financial support; C.M.-A. and P.L.M.L. led the writing; A.M., P.L. and C.M.-A. collected the data; C.M.-A., P.L.M.L. and G.C.H. analysed data and, with C.R., interpreted the results; all authors contributed comments on the whole paper as it was written.

Editor: Robert McDowall 